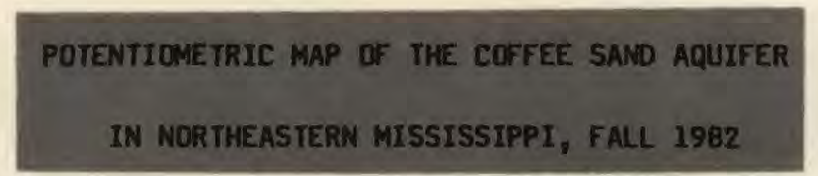

The U.S. Geological Survey, in cooperation with the Mississippi Department of Natural has prepared a series of maps of major aquifers in Mississippi to show the availability of ground water for municipal and industrial use and to show the effects of withdrawals on the aquifer. This map is the second in the series the Coffee Sand aquifer delinested the potentiometric surface in 1978 (Wasson, 1980).

The Coffee Sand of the Selma Group of Late Cretaceous age is composed chiefly of sand and clay that is locally lignitic. The aquifer Prentiss, Tippah, and northern Union Counties. The percentage of sand decreases from north to south as the sand grades into chalk of the Selme Group. The Coffee Sand is overlain and confined by the Dempolis Chalk. The Eutaw formation underlifer dips about 35 feet per mile to the west.

Precipitation recharges the Coffee Sand aquifer in the outcrop area in Alcorn, Tishomingo, Prentiss, Lee, and Itawamba counties. The regional ground-water movement is cree. The toproxinte doutcrop water. (less than 1,000 milligrams per liter of dissolved solids) in the Coffee Sand aquifer is about 40 miles west of the outcrop area and marks a boundary of this map.

The Coffee Sand aquifer contains, freshwater in an area of about 3,000 square miles in Mississippi where it is the source of ground water for many
domestic wells.

This water-level map is based on water-level measurements made in about 30 wells in the contours show altitudes at which water levels would have stood in tightly cased unpumped wells.

In and near the outcrop area, water levels in the Cof fee Sand aquifer have remained nearly
stable since 1978. Water-level declines in wells located to the west and southwest of the outcrop area ranged from 2 to 16 feet. Potentiometric surfaces in this

\section{MDOITIONAL INFORMATION}

The map showing the results of the fall 1982 water-level measurements for the Coffee Sand aquifer is the second map showing ground-water series of maps ther. These maps are part of a major aquifers in Mississippi. Data describing the individual wells used in this study may be obtained from the following:

Director

Mississippi Department of Natural Resources

Bureau of Land and Water Resource

.0. Box 10631

(601) $961-5200$ issippi 39209

District Chief

U.S. Geological Survey

Water Resources Division

Jou H. Capitol Street, Suite 7

(601) $960-4600$

Copies of this report can be purchased from

Open-File Services Section

Western Distribution Bra

Donver,

(303) 234-588B

\section{SELECTED REFERENCES}

Belt, W. E., and others, 1945, Geologic map of Mississippi: Mississippi Geological Boswe11, E. H., 1963, Cretaceous aquifers of northeastern Mississippi: Mississippi Board of Water Commissioners Bulletin 63-10, $202 \mathrm{p}$.

-1979, The Coffee Sand and Ripley aquifers Mississippi: U.S. Geological Survey 78-114, I sheet. Investigations Report Coffee Sand aquifer in in northeastern
Cons, Ber Coffee Sand aquifer in northeastern
Mississippi, October and November 1978: U.S. Geological Survey Water-Resources 1 sheet.
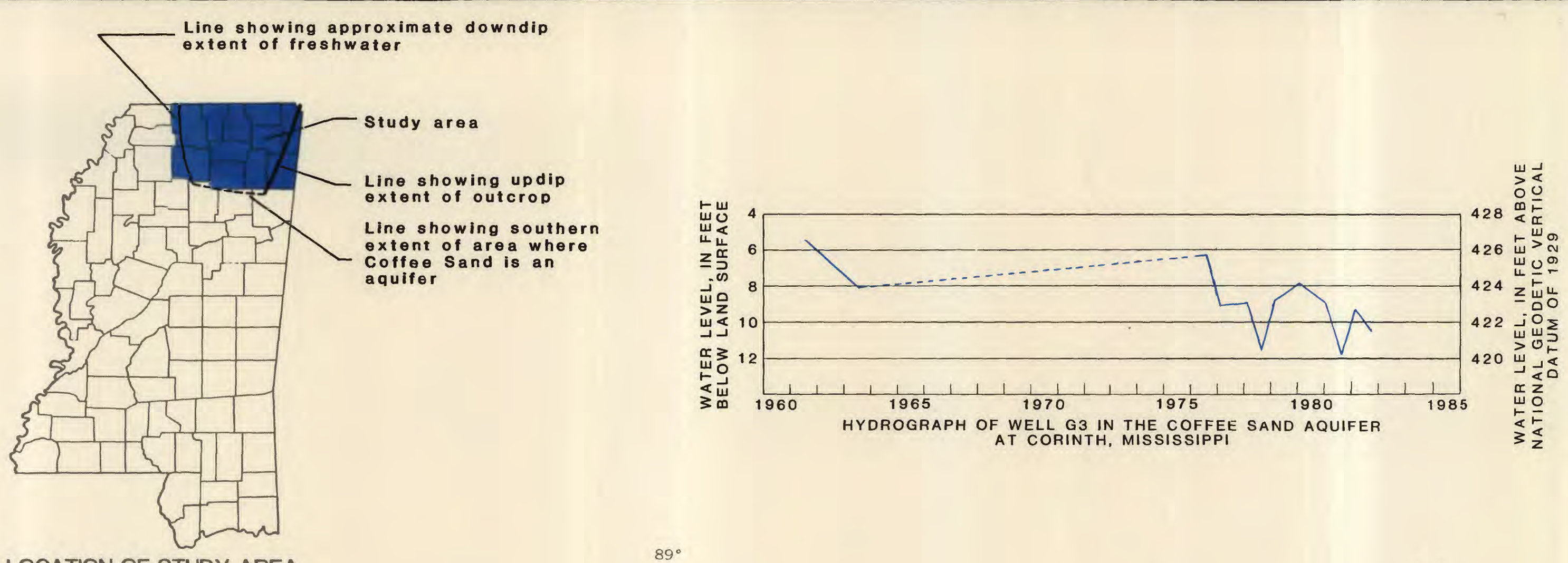

LOCATION OF STUDY AREA
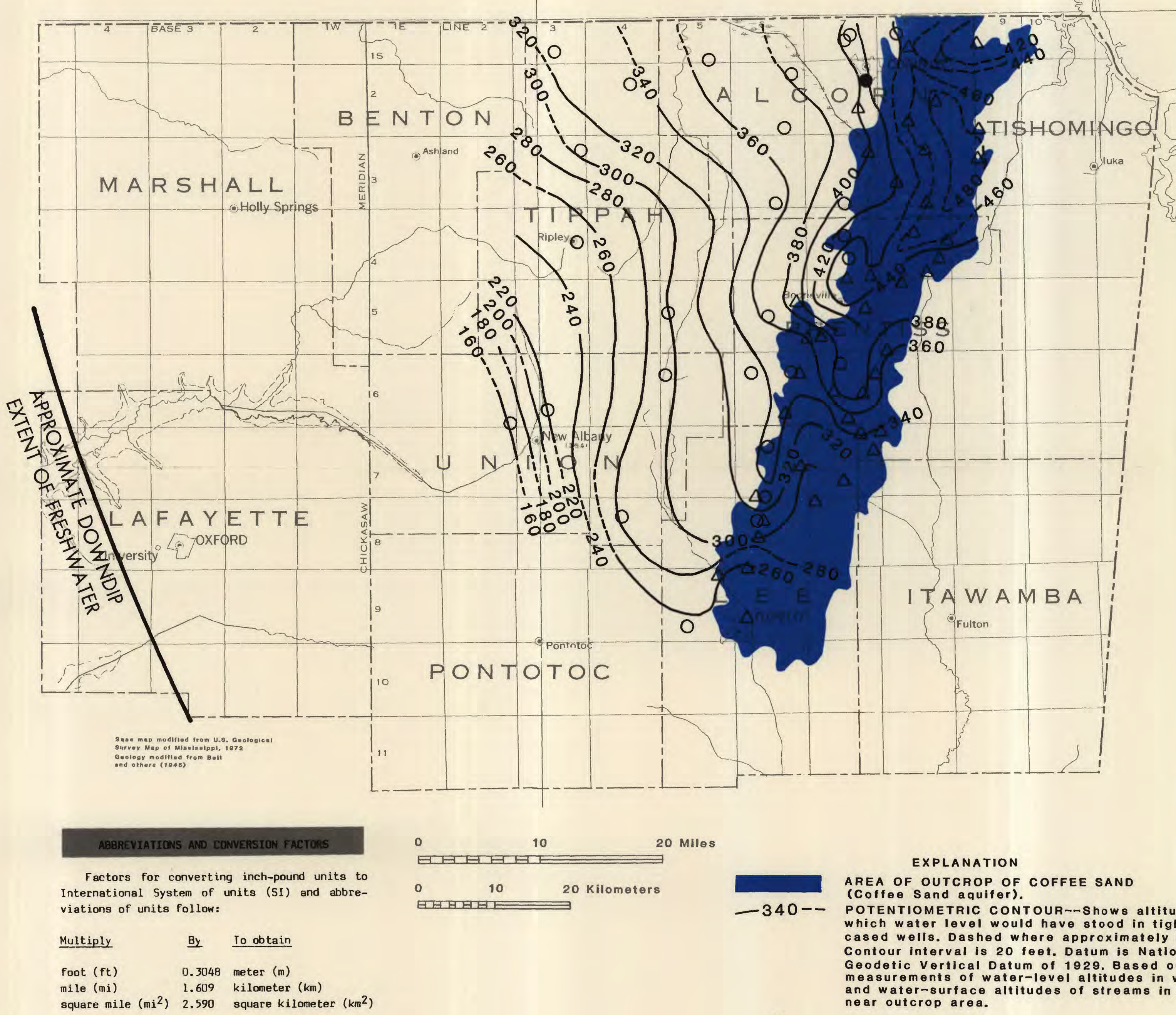

AREA OF OUTCROP OF COFFEE SAND

POTENTIOMETRIC CONTOUR--Shows altitude at approximately located. contour interval is 20 feet. Datum is National measurements of water-level altitudes in wells and water-surface altitudes of streams in and observation weLL

O OBSERVATION WELL

OBSERVATION WELL FOR WHIGH HYDROGRAPH
IS SHOWN. POINT AT WHICH ALTITUDE OF WATER SURFACE POTENTIOMETRIC SURFACE OF AQUIFER.

\section{POTENTIOMETRIC MAP OF THE COFFEE SAND AQUIFER IN NORTHEASTERN MISSISSIPPI, FALL 1982}

DAPHNE DARDEN 